\title{
EFFECT OF DIET ON ENZYMES OF THE BRUSH BORDER OF THE SMALL INTESTINE AND KIDNEY OF RATS
}

\author{
Masayuki SAITo and Masami SudA ${ }^{1}$ \\ Department of Biochemistry, School of Medicine, \\ Ehime University, Matsuyama, Ehime, Japan
}

(Received January 16, 1975)

\begin{abstract}
Summary The effect of diets containing various amounts of casein and starch on enzymes bound to the brush border of the small intestine and kidney of rats were investigated with the following results. 1) Diets with low starch and high casein contents resulted in higher specific activity of leucineaminopeptidase in the small intestine than diets with high starch and low casein contents. Diets with high starch and low casein contents increased the specific activity of maltase. 2) Rat small intestine contains at least two isoenzymes of leucineaminopeptidase: one bound to the brush border and the other not bound to it but recoverable in the soluble fraction. Only the former was influenced by the diet. 3) The maximum velocity $\left(V_{\max }\right)$ of leucineaminopeptidase bound to the brush border was twice as much in rats on a high casein diet as in those on a low casein diet, but the Michaelis constant $\left(K_{m}\right)$ was approximately the same in both groups of rats. 4) Leucineaminopeptidase and maltase activities in the kidney were not influenced by diet.
\end{abstract}

Fractionation of the epithelial cells of the small intestine has indicated that the brush border membrane binds may hydrolytic enzymes, such as maltase, sucrase, lactase, dipeptidases, leucineaminopeptidase and alkaline phosphatase. It has been suggested that some of these enzymes play a fundamental role in the terminal digestion or absorption of nutrients $(1,2)$. The effects of dietary conditions on these enzymes, especially on disaccharidases, have been reported by several workers $(3,4)$. DEREN et al. (4) demonstrated that administration of a diet containing carbohydrate to fasted rats caused a twofold increase in sucrase and maltase activities. They found that a diet containing sucrose caused a greater increase in sucrase activity than in maltase, whereas a diet containing maltose had the opposite effects, suggesting that these enzymes were specifically induced by the respective disaccharides. Alkaline phosphatase was also found to be affected

\footnotetext{
1 斎藤昌之，須田正己
} 
by the diet (5). However there are few reports on the effects of a diet on the peptide-hydrolyzing enzymes of the brush border. Leucineaminopeptidase, like disaccharidases, seems to take part in the final stage of digestion of foods, so it may also show adaptive changes to diet, especially when animals are fed on high protein diets. To study this possibility, rats were given diets with various starch and casein contents and the activities of maltase and leucineaminopeptidase bound to the brush border in the small intestine were measured. These enzyme activities were also measured in the kidney, where the epithelial cells lining the proximal tubules are very similar in structure and function to those of the small intestine $(6,7)$.

\section{METHODS}

Male Wistar strain rats (150-200 g) were fed on commercial laboratory chow (Oriental Yeast Co.) and kept in wire-bottomed cages at $22 \pm 2^{\circ} \mathrm{C}$ for at least 1 week before experiments. Then, they were separated into groups and given synthetic diets with various starch and casein contents for 5 days, as shown in Table 1 . For examination rats were usually decapitated between 12:00 and 14:00 because, as reported previously $(8)$, when rats were fed ad libitum the enzyme activities bound to the intestinal brush border show daily rhythmic changes, being high at night and low in the daytime, but showing no significant change between 12:00 and 14:00. After decapitation, the entire small intestine and the kidneys were rapidly removed. The small intestine was washed out with cold $0.9 \% \mathrm{NaCl}$ and everted. The mucosa was collected by scraping the intestine with a glass slide. The kidneys and the intestinal mucosa were homogenized separately with about 10 volumes of $10 \mathrm{~mm}$ Tris- $\mathrm{HCl}$ buffer ( $\mathrm{pH} \mathrm{7.0)}$ in a teflon-pestle homogenizer. These homogenates were used for enzyme assays unless otherwise indicated.

Leucineaminopeptidase bound to the brush border was solubilized with Triton $\mathrm{X}-100$ as follows. The intestinal homogenate was centrifuged at $100,000 \times g$ for $1 \mathrm{hr}$, and the resulting precipitate was incubated with $0.5 \%$ Triton $\mathrm{X}-100$ and $1 \mathrm{mg}$ protein $/ \mathrm{ml}$ in $10 \mathrm{~mm}$ Tris- $\mathrm{HCl}$ buffer $(\mathrm{pH} 7.0)$ at $37^{\circ} \mathrm{C}$ for $30 \mathrm{~min}$. Then the

Table 1. Compositions of Synthetic Diets. Diets A and B are high starch and low casein diets and diets $\mathrm{C}$ and $\mathrm{D}$ are low starch and high casein diets.

\begin{tabular}{lcccc}
\hline & \multicolumn{4}{c}{ Content (g per 100 g diet) } \\
\cline { 2 - 5 } & A & B & C & D \\
\hline Casein & 5 & 20 & 76 & 91 \\
Starch & 71 & 56 & 0 & 0 \\
Sucrose & 15 & 15 & 15 & 0 \\
Fat mixture & 2 & 2 & 2 & 2 \\
Salt mixture & 4 & 4 & 4 & 4 \\
Vitamin mixture & 1 & 1 & 1 & 1 \\
Cellulose powder & 2 & 2 & 2 & 2 \\
Choline chloride & 0.1 & 0.1 & 0.1 & 0.1 \\
\hline
\end{tabular}


mixture was dialyzed overnight against $10 \mathrm{~mm}$ Tris- $\mathrm{HCl}$ buffer ( $\mathrm{pH} 7.0$ ) to remove most of the Triton $\mathrm{X}-100$. After dialysis the preparation was recentrifuged at $100,000 \times g$ for $1 \mathrm{hr}$, and the resulting supernatant, in which the leucineaminopeptidase was recovered completely, was employed as solubilized leucineaminopeptidase from the brush border.

DEAE-cellulose column chromatography was carried out as follows. DEAEcellulose (Serva Co.) was packed in a column $(1 \times 14 \mathrm{~cm})$ and was equilibrated with $10 \mathrm{~mm}$ Tris- $\mathrm{HCl}$ buffer ( $\mathrm{pH} \mathrm{7.0)}$. The column was eluted with the same buffer containing a continuous gradient of $0-0.5 \mathrm{M} \mathrm{NaCl}$ at a flow rate of about $10 \mathrm{ml} / \mathrm{hr}$ and $2.5 \mathrm{ml}$ fractions were collected.

Leucineaminopeptidase activity was measured in a reaction mixture containing $0.6 \mathrm{mM}$ L-leucyl- $\beta$-naphthylamide, $1 \mathrm{mM} \mathrm{CoCl}_{2}, 80 \mathrm{~mm}$ sodium phosphate buffer ( $\mathrm{pH} 7.0$ ) and enzyme (10-50 $\mu \mathrm{g}$ protein) in a total volume of $0.25 \mathrm{ml}$. After incubation at $37^{\circ} \mathrm{C}$ for $10 \mathrm{~min}$, the reaction was terminated by adding $0.25 \mathrm{ml}$ of $10 \%$ trichloroacetic acid, and the $\beta$-naphthylamine formed was measured by the method of GoldBerg and Rutenberg (9). Maltase activity was determined by a slight modification of DAHLQVIST's method (10). The assay was performed in a reaction mixture containing $25 \mathrm{~mm}$ maltose, $25 \mathrm{~mm}$ sodium phosphate buffer ( $\mathrm{pH} \mathrm{7.0)}$ and enzyme (10-50 $\mu \mathrm{g}$ protein) in a total volume of $0.25 \mathrm{ml}$ at $37^{\circ} \mathrm{C}$ for $10-30 \mathrm{~min}$. The reaction was stopped by heating the mixture for $1 \mathrm{~min}$ in a boiling water bath. The glucose liberated was estimated using specific glucose oxidase reagents (Worthington Biochemical Co.). Protein was estimated by the method of LowRY et al. (11) with bovine serum albumin as standard. All procedures were performed at $0-4{ }^{\circ} \mathrm{C}$ unless otherwise noted.

\section{RESULTS}

Maltase activity was measured in homogenates of the small intestinal mucosa and of the kidney of rats that had been fed on diets containing 5, 20, 76 and $91 \%$ casein for 5 days. In the small intestine, the mean maltase activity in rats fed on $5 \%$ casein was $392 \pm 27 \mathrm{~m} \mu \mathrm{moles} / \mathrm{min} / \mathrm{mg}$ protein. The activity was similar in rats fed on $20 \%$ casein diet, being $382 \pm 32 \mathrm{~m} \mu \mathrm{moles} / \mathrm{min} / \mathrm{mg}$ protein. However, diets with higher casein and lower starch contents caused significant decrease in the enzyme activity to $273 \pm 6$ and $280 \pm 27 \mathrm{~m} \mu \mathrm{moles} / \mathrm{min} / \mathrm{mg}$ protein in rats fed on 76 and $91 \%$ casein diets, respectively (Fig. 1). Thus, the specific activity of maltase in the small intestine increased in rats on high starch and low casein diet. The maltase activity in the kidney was similar in all groups of rats.

To study the effect of diet on the peptide hydrolyzing activity, the leucineaminopeptidase activity was measured in the small intestine of rats on these diets. As shown in Fig. 2, the specific activities of leucineaminopeptidase were $73.7 \pm 6.7$ and $74.9 \pm 5.7 \mathrm{~m} \mu \mathrm{moles} / \mathrm{min} / \mathrm{mg}$ protein in rats on 5 and $20 \%$ casein diets, respectively, but increased significantly to $126 \pm 3$ and $140 \pm 12 \mathrm{~m} \mu \mathrm{moles} / \mathrm{min} / \mathrm{mg}$ protein 


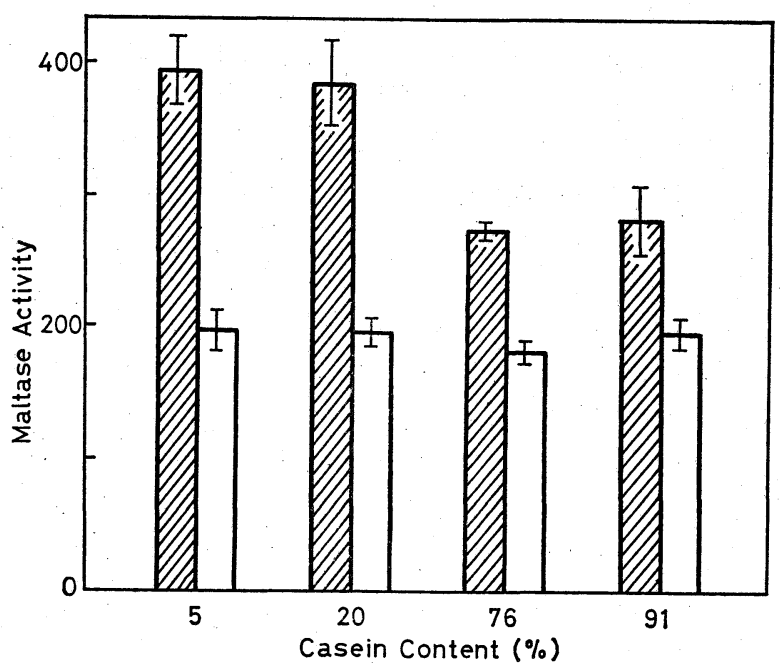

Fig. 1, Effects of diet on maltase activities in the samll intestine and kidney. Maltase

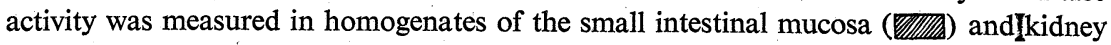
( $\square$ ) of rats fed diets containing 5, 20, 76 and $91 \%$ casein for 5 days. Enzyme activity is expressed as $\mathrm{m} \mu$ moles of product formed per minute per mg protein. Values are means of those in five rats with standard errors.

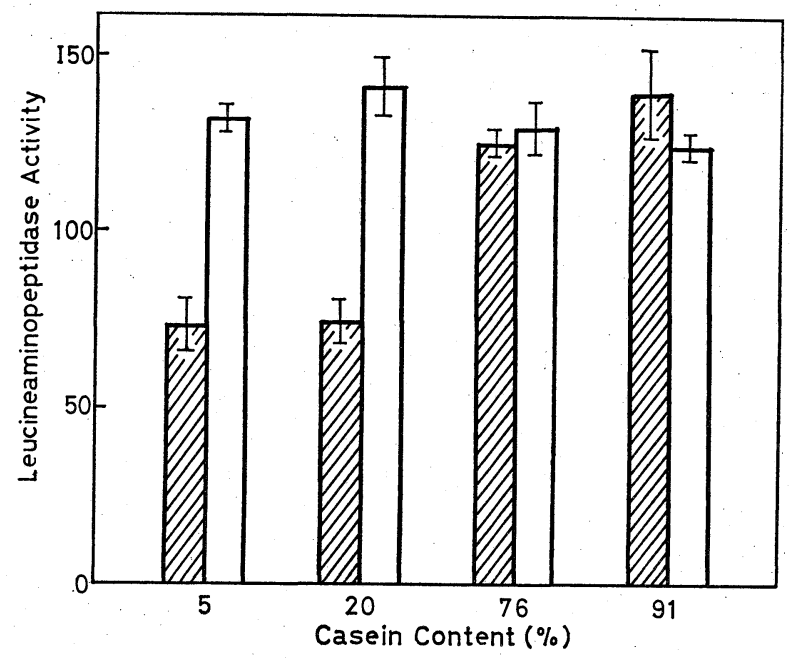

Fig. 2. Effects of diet on leucineaminopeptidase activities in the small intestine and kidney. Leucineaminopeptidase activity was measured in homogenates of the small intestinal mucosa ( is expressed as $\mathrm{m} \mu$ moles of product formed per minute per $\mathrm{mg}$ protein. Values are means of those in five rats with standard errors. 
in rats on 76 and $91 \%$ casein diets, respectively. These results indicate that leucineaminopeptidase in the small intestine is influenced by the diet, and that in contrast to maltase activity, its specific activity increased in rats on a low starch and high casein diet. Renal leucineaminopeptidase activity did not show any significant difference in rats on low and high casein diets.

Cell fractionation studies have shown that maltase activity is exclusively bound to the brush border of the small intestinal mucosa, while leucineaminopeptidase activity is detected in both the brush border and the soluble fraction. For the study shown in Fig. 2, the whole homogenate was used to measure the leucineaminopeptidase activity, and therefore the results do not show whether the isoenzyme bound to the brush border or the soluble isozyme is affected by the casein content of the diet. To separate the isozyme bound to the brush border from the soluble one, the homogenate of intestinal mucosa was centrifuged at $100,000 \times g$ for $1 \mathrm{hr}$. In this way at least $90 \%$ of the total activity in the initial homogenate was recovered in the precipitate. It was found that the specific activity in the precipitate was about twice as great when rats were fed on $91 \%$ casein diet as when they were fed on $5 \%$ casein diet. Thus, these results indicated that the changes in leucineaminopeptidase activity shown in Fig. 2 represented mainly, if not entirely, changes in leucineaminopeptidase activity bound to the brush border.

Next the problem was examined of whether the soluble leucineaminopeptidase in the small intestine is also affected by the diet. The supernatant obtained by centrifugation at $100,000 \times g$ for $1 \mathrm{hr}$ contains the soluble leucineaminopeptidase, but it may be contaminated by the enzyme from brush border, liberated by partial autodigestion of the brush border. To separate the soluble leucineaminopeptidase from that liberated from the brush border, an aliquot of the supernatant was applied to a DEAE-cellulose column. As indicated in Fig. 3, the supernatant contained at least two leucineaminopeptidases, one eluted with $0.12 \mathrm{M} \mathrm{NaCl}$ and the other with $0.23 \mathrm{M} \mathrm{NaCl}$. The amount of the former increased when the initial homogenate was incubated for $1 \mathrm{hr}$ at $37^{\circ} \mathrm{C}$ before centrifugation, suggesting that this fraction is liberated from the brush border by autodigestion. Furthermore, leucineaminopeptidase solubilized from the brush border with Triton $\mathrm{X}-100$ as described in the Methods was eluted as a single peak with $0.12 \mathrm{M} \mathrm{NaCl}$ (Fig. 3). Thus these results indicate that the leucineaminopeptidase eluted with $0.12 \mathrm{M} \mathrm{NaCl}$ is from the brush border, while that eluted with $0.23 \mathrm{M} \mathrm{NaCl}$ is the soluble or cytoplasmic leucineaminopeptidase in situ. The effect of diet on the latter fraction was studied as follows. Homogenates of the intestinal mucosa of rats which had been fed on 5 and $91 \%$ casein diets were centrifuged at $100,000 \times g$ for $1 \mathrm{hr}$, and then aliquots of each of the resulting supernatants were applied to a DEAEcellulose column in each, and the activities eluted with $0.23 \mathrm{M} \mathrm{NaCl}$ were measured. The mean specific activities with the standard errors in four experiments were $11.3 \pm 0.7$ and $11.0 \pm 1.2 \mathrm{~m} \mu \mathrm{moles} / \mathrm{min} / \mathrm{mg}$ protein of supernatant from rats on 5 and $91 \%$ casein diets, respectively. Thus the soluble leucineaminopeptidase in 


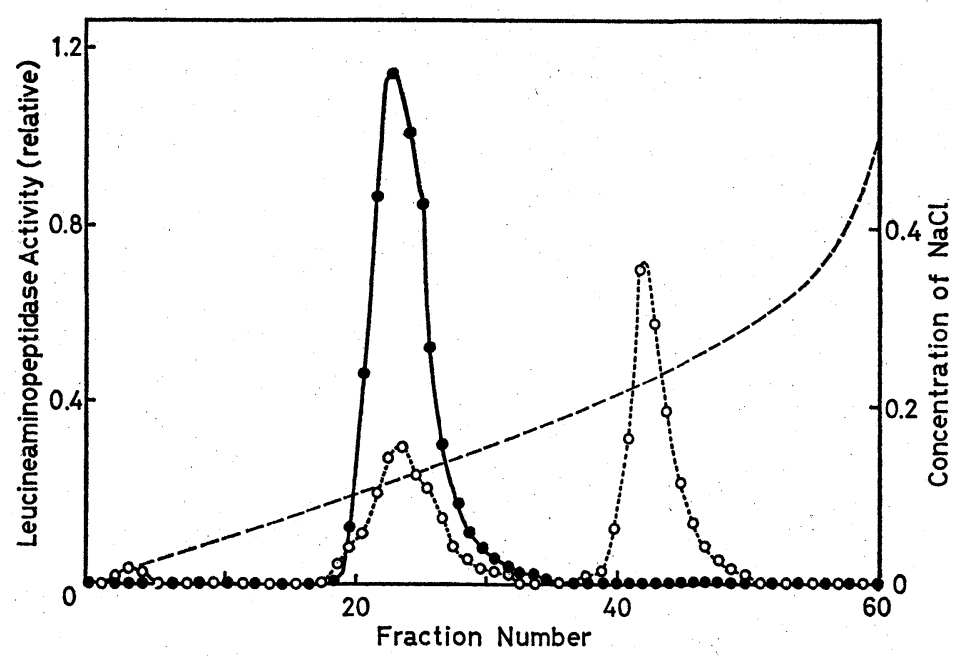

Fig. 3. Elution of intestinal leucineaminopeptidases from a DEAE-cellulose column. In one experiment $(\mathrm{O}--\mathrm{O})$, the supernatant obtained by centrifugation of the intestinal

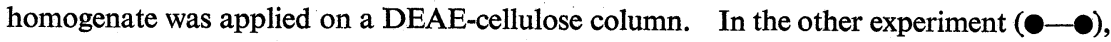
the sediment obtained by centrifugation of the homogenate was treated with Triton X100 , dialyzed and recentrifuged and the resulting supernatant was applied to the column. The column was eluted with a continuous $\mathrm{NaCl}$ gradient (-- ), and the leucineaminopeptidase activity of each fraction was measured. Experimental details are described in the text.

the small intestine does not seem to be influenced by the diet, in contrast to that of the brush border.

Under the experimental conditions shown in Fig. 2, the leucineaminopeptidase activity was measured at a fixed, subsaturating concentration of substrate of $0.6 \mathrm{~mm}$. Thus it is uncertain which kinetic parameter preferentially contributes to the change in enzyme activity. Accordingly, the intestinal and renal leucineaminopeptidase activities in rats fed on 5 and $91 \%$ casein diets were measured at various substrate concentrations. The activities were measured in the precipitates obtained by centrifugation of the homogenates at $100,000 \times g$ for $1 \mathrm{hr}$. The leucineaminopeptidase activity from the small intestine of rats on $91 \%$ casein diet was greater than that of enzyme from rats on $5 \%$ casein diet at all substrate concentrations tested. As shown in Fig. 4, Lineweaver-Burk plots clearly indicated that diet of high casein content elicited a significant increase in the maximum velocity, $V_{\max }$, but had no effect on the Michaelis constant, $K_{m}$. Table 2 summarizes the effects of diet on the kinetic characteristics of the intestinal and renal leucineaminopeptidases. The values of $K_{m}$ of the intestinal and renal enzymes were not influenced by the dietary casein content. In the small intestine, the value of $V_{\max }$ of enzyme from rats on $91 \%$ casein diet was much higher than that of rats on $5 \%$ casein diet, whereas in the kidney the $V_{\max }$ value of the two groups were approximately the same. 


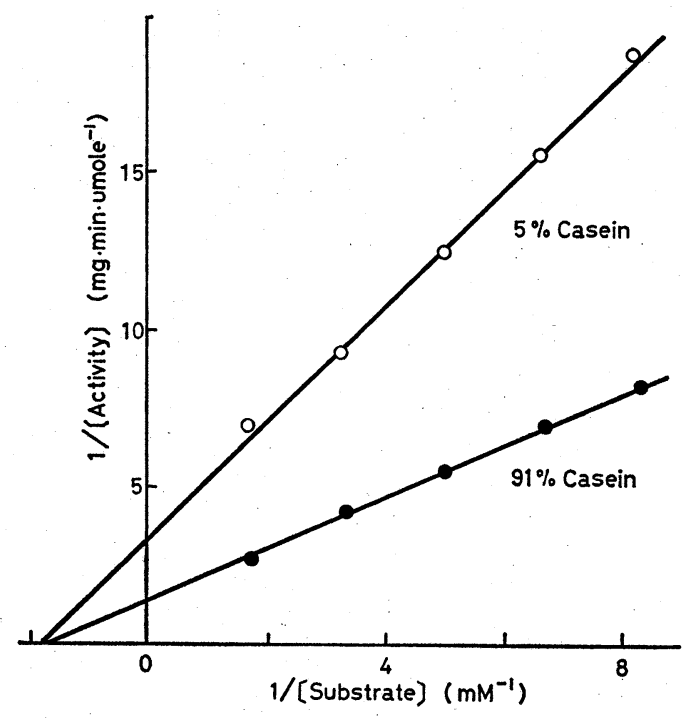

Fig. 4. Lineweaver-Burk plots for leucineaminopeptidase from the small intestine of rats on 5 and $91 \%$ casein diets. Activity in the precipitates obtained by centrifugation of intestinal homogenates were assayed at various concentrations of substrate $(0.12-0.6 \mathrm{~mm})$.

Table 2. Effect of diet on the kinetic characteristics of the intestinal and the renal leucineaminopeptidases. The means of the $K_{m}$ and $V_{\max }$ values in four rats of the leucineaminopeptidases in the small intestine and kidney were indicated with standard errors.

\begin{tabular}{lccc}
\hline & $\begin{array}{c}\text { Casein content } \\
(\%)\end{array}$ & $\begin{array}{c}K_{m} \\
(\mathrm{mM})\end{array}$ & $\begin{array}{c}V_{\max } \\
(\mathrm{m} \mu \mathrm{mole} / \mathrm{min} / \mathrm{mg})\end{array}$ \\
\hline Small intestine & 5 & $0.64 \pm 0.04$ & $376 \pm 19$ \\
& 91 & $0.64 \pm 0.02$ & $829 \pm 40$ \\
\hline Kidney & 5 & $0.38 \pm 0.02$ & $397 \pm 52$ \\
& 91 & $0.39 \pm 0.01$ & $351 \pm 6$ \\
\hline
\end{tabular}

\section{DISCUSSION}

The present studies showed that in the small intestine the maltase activity in rats fed low casein and high starch diet was higher than that in rats fed high casein and low starch diet, whereas the leucineaminopeptidase activity in the former was lower than in the latter. These results confirm the reports that dietary carbohydrate influences intestinal disaccharidases $(3,4)$, and also indicate that the intestinal leucineaminopeptidase is also influenced by the diet. These reverse changes in maltase and leucineaminopeptidase activities caused by the starch and casein contents seem understandable, since these enzymes are probably important for digestion of the diet. A similar pattern of response of trypsin, chymotrypsin 
and amylase to the diet was observed in rat pancreas (12). It is interesting that leucineaminopeptidase bound to the brush border was influenced by the diet while the unbound enzyme, recovered in the soluble fraction was not. These findings suggest that the mechanisms of regulation of these two isoenzymes are different.

The reverse changes of maltase and leucineaminopeptidase may be caused by some unknown specific factors functioning separately for each enzyme, and may represent changes in the numbers of molecules of each enzyme per cell rather than changes in the population of cells which bind the enzymes. The increased leucineaminopeptidase activity presumably represents increase in the quantity of the enzyme. The findings that the $K_{m}$ value of the leucineaminopeptidase was approximately the same in rats on low and high casein diets, while the $V_{\max }$ value was twice as great in the latter is best explained as due to a twofold increase in the quantity of enzyme in rats on high casein diet. A similar explanation was proposed by DEREN et al. (4) for the dietary change in the intestinal disaccharidase activity.

In preliminary experiments we observed that the changes of maltase and leucineaminopeptidase activities followed a similar time course and that the rise and the fall in the respective enzyme activities were completed within two to three days and then remained unchanged. The time course of these changes seems to be nearly the same as the turnover time of intestinal cells (13). Therefore, it is quite possible, as suggested by Rosensweig and Herman (14), that the changes caused by dietary alterations are mediated through the crypt cells. However, DEREN et al. (4) showed that sucrase and maltase activities are inducible within $24 \mathrm{hr}$ on feeding appropriate carbohydrate after 3 days fasting. Furthermore, recent studies (15) on the turnover of enzymes in the intestinal brush border demonstrated that disaccharidases are synthesized and catabolized during migration of epithelial cells and that individual brush border proteins do not necessarily have a uniform turnover rate. These observations suggest the alternative possibility that the enzyme activities bound to the brush border may be modified in the mature villus cell by dietary alterations. Further studies are needed on the actual mechanism of the dietary response of enzymes bound to the intestinal brush border.

The present studies show that in contrast to the intestinal enzymes maltase and leucineaminopeptidase in the kidney are not influenced by the diet. Furthermore, as reported in the previous paper ( 8 ), brush border enzymes in the kidney do not show daily rhythmic changes like those in the small intestine. These findings suggest that metabolic regulation of epithelial cells in the kidney is quite different from that of the cells in the small intestine.

\section{REFERENCES}

1) Ugolev, A. M., Biol. Rev., 45, 555 (1965).

2) Crane, R. K., in C. F. Code and W. Heidel (Editors), Handbook of Physiology, Section 6, Alimentary Canal, American Physiological Society, Washington, Vol. 5, p. 2535 (1968).

3) Blair, D. G. R., Yakimets, W., and Tuba, J., Canad. J. Biochem. Physiol., 41, 917 (1963). 
4) Deren, J. J., Broitman, S. A., and Zamcheck, N., J. Clin. Invest, 46, 186 (1967).

5) Tuba, J. and Dickie, N., Canad. J. Biochem. Physiol., 32, 621 (1954).

6) Shultz, S. G. and Curran, P. F., Physiol. Rev., 50, 637 (1970).

7) Berger, S. J. and SACKTor, B., J. Cell Biol., 47, 637 (1970).

8) SaIto, M., Biochim. Biophys. Acta, 281, 212 (1972).

9) Goldberg, J. A. and Rutenberg, A. M., Cancer, 11, 283 (1958).

10) Dahlevist, A., Anal. Biochem., 7, 18 (1964).

11) Lowry, O. H., Rosebrough, N. J., Farr, A. L., and Randall, R. J., J, Biol. Chem., 193, 265 (1951),

12) Abdelulil, A. B. and Desnuelle, P., Biochim. Biophys. Acta, 81, 136 (1964).

13) Loehry, C. A., Croft, D. N., Singh, A. K., and Creamer, B., Gut, 10, 662 (1969).

14) Rosensweig, N. S. and Herman, R. H., Gastroenterology, 56, 500 (1969).

15) James, W. P. T., Alpers, D. H., Gerber, J. E., and Isselbacher, K. J., Biochim. Biophys. Acta, 230, 194 (1969). 